\section{Congress embraces restraint}

\section{Washington}

NEARLY half of the US Senate has signed a letter criticizing the rapid increase of the budget sought by the Reagan administration for the Strategic Defense Initiative (SDI). The administration is asking for a 77 per cent increase in SDI funds for 1987.

The letter was addressed to Senator Barry Goldwater (Republican, Arizona), chairman of the armed services committee, which will be taking up the SDI budget request this month. The 35 Democrats and 9 Republicans say they are concerned that SDI has received "excessive and inappropriate emphasis" in the Department of Defense (DoD) budget request, threatening "vital" military research programmes.

While expressing support for "vigorous" ballistic missile defence research, the senators worry that the SDI research programme is being rushed in an attempt to meet unrealistic deadlines. The administration hopes that a decision about SDI deployment will be made in the early 1990s.

Support for SDI this year is set at $\$ 3,050$ million, of which $\$ 2,760$ million comes from DoD and the rest from the Department of Energy (DoE). For next year, the administration is seeking $\$ 5,400$ million for SDI $-\$ 4,800$ million to go to DoD and $\$ 600$ million to DoE. The senators argue that SDI funds have out-paced technological progress, and that a 3 per cent increase, allowing for inflation, will keep the programme going on an even keel.

\section{Laser cut down to size}

LOCAL residents in the predominantly rural and conservative area of California in which the Lawrence Livermore Laboratory is located have forced the laboratory to modify its plans to build a free-electron laser (FEL) too big to fit within the laboratory fence. A high-level panel under Dr George Dacey, president of the Sandia National Laboratory, has been convened to settle the issue.

The Livermore FEL is part of the development of the Strategic Defense Initiative (SDI) and in its original form would have cost $\$ 1,000$ million. The device was to have been a $300 \mathrm{MeV}$ induction linac (linear accelerator) designed to produce 1 $\mu \mathrm{m}$ radiation at a power of $100 \mathrm{MW}$.

Local opposition to the proposal to extend the laboratory's perimeter fence to accommodate such a large machine has led Livermore to propose a new plan for two FELs operating at half the linac voltage $(150 \mathrm{MeV})$, one at the laboratory and one at the army range at White Sands, New Mexico. The second FEL would be
The House of Representatives may take an even more restrictive approach to the SDI budget. Representative Charles Bennett (Democrat, Florida), a member of the House Armed Services Committee, believes there is backing for a freeze at the present year's level of support. This committee will also be considering the SDI appropriations request this month.

The White House has reacted quickly to this rebuke from the Senate. The President's spokesman Larry Speakes said the administration "disagrees strongly" with the letter's recommendation, and urged Congress to support the President's budget request.

In future, the administration should have a new ally in its battle for support of SDI. The Science and Engineering Committee for a Secure World, comprised of some 77 scientists and engineers, believes SDI deserves the "full support of the scientific community, Congress and the American people". Fred Seitz, president emeritus of Rockefeller University and acting chairman of the committee, says the group was formed in response to recent efforts by academics opposed to SDI (see Nature 321, 369; 1986). Spokesman John Kwapisz says that one of the committee's chief goals is to correct the growing public misconception that all scientists and engineers oppose SDI. But with no financial support and no clear agenda for the future, Seitz says he cannot tell how large a part the committee will play in the debate over SDI.

Joseph Palca

capable of being upgraded to $300 \mathrm{MeV}$.

Enthusiasm at Livermore for free-electron lasers as part of the SDI programme stems from the recent success of the 1.5 $\mathrm{MeV}$ induction linac at Livermore, at which $\mathbf{4 0}$ per cent of the beam energy is converted into $3 \mathrm{~cm}$ radiation. The larger versions would incorporate long tapering "wiggler" sections for generating radiation output by the motion of fast electrons through a corrugated magnetic field.

Among the outstanding problems are the construction of a pair of laser mirrors separated by $4 \mathrm{~km}$ so as to match the linac beam. Another problem faces the "second" FEL - apparently neither Livermore nor the US Army will accept responsibility for its maintenance.

Livermore is now the main centre in the United States for military FEL research, with a budget of $\$ \mathbf{8 0}$ million a year. As with many other SDI elements, supporters argue that recent developments constitute a major breakthrough; opponents of the ground-based FEL system say it would be, at best, cumbersome and vulnerable.
Neolithic Jericho Ancient wall
theory teeters

Rehovoth

Hebrew University Professor Ofar BarYosef seems bent on seeing the walls of Jericho come tumbling down again. BarYosef says that the structure identified by the British archaeologist, the late Dame Kathleen Kenyon, as part of a mediaeval city wall, was in fact part of a flood control system used by farmers to control the flow of water from neighbouring wadis. If confirmed, this may mean that Jericho was not the world's first walled city.

This development has emerged from a programme of research that has thrown new light on the first use by farmers of cereals in the Middle East. Bar-Yosef has, for example, excavated from the site of another Neolithic village at the brief settlement of Netiv Hagdud, $15 \mathrm{~km}$ to the north of Jericho, samples of carbonized grain which, according to Mordechai Kislev, contain both wild and cultivated barley dating from the period $8,200 \mathrm{BC}$ to $7,500 \mathrm{BC}$.

The fact that both wild and cultivated barley were found at the same site suggests that both were growing there 10,000 years ago. Bar-Yosef believes that his new find is the earliest record of the use of cultivated cereals, and he believes that wheat as well as barley was part of the Neolithic farming pattern. By the biblical era, the use of cereals was sufficiently well established to support the well-known statement in Deuteronomy that "Man doth not live by bread alone...".

Several research groups in Israel are involved with the search for the origin of modern cereals. Since the discovery almost exactly eighty years ago of a surviving primordial wild wheat plant growing out of a crevice in a rock near the village of Rosh, in what was then Turkish Palestine, much has been done to conserve these ancient plants. The agronomist Aaron Aaronsohn who found the first plant, followed by others in Syria and trans-Jordan in succeeding years, had hoped to transfer some of the genetic characteristics of the wild wheat to the commercial strains, but breeding techniques at the time were not good enough. But now Professor Moshe Feldman at the Wiezmann Institute, by manipulating chromosomal segments, claims to have incorporated some of the ancient genes into commercial strains of wheat that yield as much as existing varieties but boast a protein content up to six per cent greater.

Meanwhile, Feldman and his colleagues are asking that the existing fields of wild wheat will be carefully fenced off so as to preserve the pristine genetic constitution of the plants.

Nechemia Meyers 